\title{
Analysis of Genius Loci Concept Implementation on The Go Green Glintung Thematic Kampong in Malang City
}

\author{
${ }^{1}$ Debri Haryndia Putri \\ ${ }^{1}$ Interior Design Field Of Graphic Design Departement, Vocational \\ Programme \\ ${ }^{1}$ Brawijaya University, Malang, Indonesia \\ haryndiaputri@gmail.com
}

\author{
${ }^{2}$ Titi Ayu Pawestri \\ ${ }^{2}$ Interior Design Field Of Graphic Design Departement, Vocational \\ Programme \\ ${ }^{2}$ Brawijaya University, Malang, Indonesia \\ ${ }^{1}$ haryndiaputri@gmail.com, ${ }^{2}$ titipawestri@ub.ac.id
}

\begin{abstract}
Thematic kampong is one of the government's efforts to overcome the problem of settlements aimed at improving the quality of the environment through the area arrangement and development based on the unique and dynamic local potency. Currently, Malang has about 78 thematic kampongs and one of them is The Go Green Glintung (3G) Thematic Kampong, whose development is based on reforestation. The emergence of various Malang's thematic kampongs regardless of the local uniqueness values is the main problem of this research. So, the purpose of this research is analyzed the implementation of Genius Loci concept to the 3G Thematic Kampong as a design guideline in the development of The 3G Thematic Village which is one of the potential tourist destinations in Malang. The concept of Genius Loci means the authentic of a certain locality that forms the spirit of place where the spirit makes the place "alive". In interpreting the spirit of a place, the user space experience towards environment is the measuring tools in this study. Therefore, this research is using qualitative descriptive method with phenomenology approached. The result of this research shows that Genius Loci in The 3G Thematic Village is located in its green spaces that formed through cultural elements. Their community lifestyle and customs through community collaboration and awareness of improving environmental conditions have been succeeded in shaping the authenticity of locality in its man-made place development as a form of community understanding to nature.
\end{abstract}

Keywords: thematic kampong, genius loci, reforestation

\section{INTRODUCTION}

Kampong city is a form of settlement in urban areas with the characteristics such as the resident that still carries their rural life behavior that is intertwined in close family ties, physical condition of the building and the environment is not good and irregular, the density of buildings and population are high, as well as the lacking of basic infrastructure availability such as clean water, sewerage, waste disposal and others refer simply to the reference number, as in [1]. As the second largest city in East Java, Malang has kampong city settlements reached 608.6 hectares and is spread in 29 points. To overcome this, in the past two years, the city government of Malang continues to try to revitalize the slum village into a thematic kampong that is habitable and has the potential to become a tourist destination.

Thematic kampong is a government's effort to overcome poverty, especially about the fulfillment of basic needs, stimulating the local economy by exploring the economic potentials of the community as a stimulus for regional development, as well as improving the quality of the community's residential environment refer simply to the reference number, as in [2]. The concept of thematic village development itself must be oriented to the search of ideas and the formation of distinctive and unique ideas that actively involve the community so that the settlement space that is being formed can be sustainable refer simply to the reference number, as in [3]

Genius Loci in architecture is a concept of place interpretation originating from the Romans who believed that every place has a soul refers simply to the reference number, as in [4]. A place is part of a space with identity, local color, smell, climate sound, legend and its own history. Thus, the concept of Genius Loci or the spirit of place or sense of place is a subjective individual's experience as a result of observations of relationships, dialogue and interactions created between humans and their environment formed from activities related to religion, social and culture of society or humans occupants of the place refer simply to the reference number, as in [5]. The implementation of the Genius Loci concept in a man-made environment must to have 4 functions, as follows:

- Physical control (climate control for nature balance)

- Functional frame (space function for human activities)

- Social Milleau (social system representation as a single entity)

- Cultural Symbolization (cultural symbol as manmade object)

From the explanation above, besides providing its own selling points that distinguish the character of a place, Genius Loci can also provide sustainability in people's lives.

Currently, Malang has 78 thematic kampongs. The Glintung Go Green (3G) kampong is one of the thematic villages in Malang which has a unique development concept in greening and water conservation.. The 3G Kampong is considered quite potential and successful in its development; its emergence thus becomes part of a millennial trend and lifestyle to who like to do selfportraits in unique places. But unfortunately, the existence of the thematic village is merely a visual not yet a part of the daily life of the citizens. If at any time, when the trend of thematic villages had faded and the level of 
tourist visits began to decrease, there would be no sustainability for people's lives in that kampong.

From the background exposure and the problems above, this study aims to evaluate the implementation of the genius loci concept to The 3G Kampong Malang. The results of this evaluative study are expected to contribute to the 4 forming components of the creative economy in the City of Malang (Government-Academics-Actors of Creative Industries \& Communities) so that another thematic villages development in the city of Malang could have a high level of sustainability.

\section{METHODS}

This study uses qualitative methods with a phenomenological approach. In collecting preliminary data, researchers observed the condition of The $3 \mathrm{G}$ Kampong directly while doing some in-depth interviews with the the $3 \mathrm{G}$ Kampong community. Phenomenological qualitative method was used by researchers to describe The 3G Kampong potency from the implementation of Genius Loci parameters including physical control, functional frames, social milleu, cultural symbolization as a sustainability manifestation of the $3 \mathrm{G}$ Kampong as a thematic kampong of potential tourist destinations in Malang.

\section{ANALYSIS \& DISCUSSION}

\section{A. General Overview of The $3 G$ Kampong}

The $3 \mathrm{G}$ Kampong was once a slum area with various social and environmental problems. Geographically, this kampong is located on Jl. S. Parman, RW 23, Kelurahan Purwantoro, Blimbing District, Malang City, East Java. In the North of the kampong bordered by RW 06 Kelurahan Purwantoro, in the South bordered by RW 05 Kelurahan Purwantoro, on the West by Jalan Raya Parman, which is the main road of Malang-Surabaya, and on the East bordered by the railroad. Administratively, the $3 \mathrm{G}$ Kampong consists of 4 neighborhoods (RT), 290 families, with a population of around 1,154 people. The majority of residents work as laborers, small entrepreneurs and private employees.

Before this village was established, the Glintung area was a water infiltration area that worked very well. Along with the people's need for a place to live, the village of $3 \mathrm{G}$ becomes congested and causes many problems including:

- Floods during the rainy season due to reduced soil infiltration capacity and the presence of drainage channels that cannot accommodate surface runoff,

- Drought during the dry season due to shallow groundwater wells caused by a decrease in soil infiltration capacity.

- Poor residential infrastructure such as damaged roads and high crime rates

- Low level of public health, where many people suffer from degenerative diseases due to poor quality of the environment.

- Low level of community incomes.

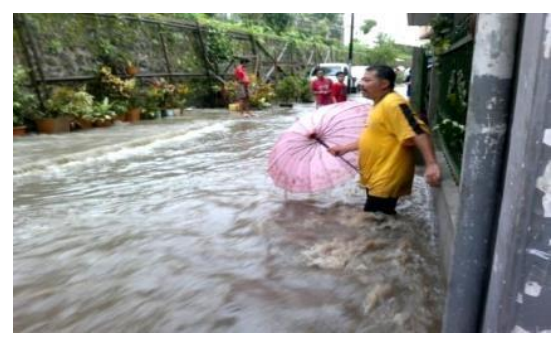

Figure.1. Floods is the main problem in the 3G Kampong (researcher documentation, 2018)

Seeing these conditions, in 2012, the kampong chairperson, Ir. H. Bambang Irianto, tries to change the situation of the kampong together with the community. His initiative is to change the face of the kampong which is manifested in a social reforestation movement called Glintung Go Green (3G). In 2013, this movement showed real results, the community began to realize the importance of a healthy residential environment due to the improving condition of the $3 \mathrm{G}$ Kampong and free from flooding. This has led to a number of innovations from community that were followed up by academics and the government through Dewandaru Garbage Bank and the Water Saving Movement. In 2014 to 2018, Kampong 3G received many awards as a thematic village based on reforestation and water conservation. The climax was the election of Malang City through the Movement of Water Saving - 3G Kampong as 15 shortlisted city for the Guangzhou International Award of Urban Innovation.

\section{B. Analysis and Evaluation of Physical Control Aspect}

The role and function of physical control on the built environment includes climate control (air, humidity, temperature, wind, rainfall, etc.), light, sound, smell, and other things such as dust, smoke, insects, animals and humans. Most of the factors mentioned above are geographic and can be understood that all aspects of physical control are related to the relationship between the built environment and its natural environment. The natural environment affects the built environment with energies that must be controlled. The aspect of physical control is very dependent on human activities that must be served and accommodated by the built environment. Those statements refer simply to the reference number, as in [4]

In The 3G Kampong, the most prominent physical control is the reforestation and water conservation movement. The reforestation movement is intended to reduce the threat of flooding, controlling the public's need for clean air, maintaining air humidity, protecting settlements from excessive sunburn, and reducing environment temperature and noise handling due to the proximity of residential areas to highways and railroads. Visually, this movement is visible through presence of plants such as vegetables, hydroponics, togas, and flowers in the kampong entrance, village boundary walls along the main road, and in public areas such as parks and front yard of people's houses. 

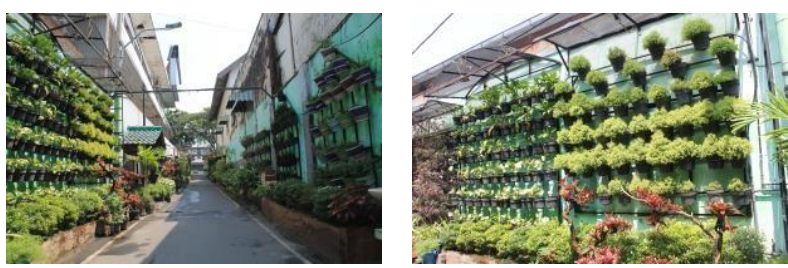

Figure.2. Main road visualization of the 3G Kampong. (Researcher documentation, 2018)

This reforestation movement was not done instantly in public areas, but started from the private space of the community by changing the community's mindset first. This mindset changing is also controlled by the policy of the kampong chairperson as the leader through his authority to give signature on citizen's letter whenever and wherever as long as the residents have planted. The planting media is not conventional because it uses used items as pots.

To control the availability of clean water, the $3 \mathrm{G}$ Kampong has made water conservation innovations through Water Savings Movement (Gemar), injects as much water as possible into the soil through biopores infiltration holes with various variants such as, infiltration ditches, infiltration control tubs and injection wells. Once it rains, these water conservation tools can store up to 101,300 liters of water. The existence of this $80-100 \mathrm{~cm}$ diameter injection well does not only affect water storage, but also bring some good impact on the environmental conditions of the $3 \mathrm{G}$ Kampong. The benefits of injection wells include:

- Increasing the ability of soil infiltration so that the drainage can accommodate surface runoff thus the points of inundation and flooding are reduced.

- Maintaining and increasing groundwater levels.

- Reducing erosion and sedimentation

- Preventing land subsidence

- Reducing the concentration of groundwater pollution

The existence of the bio pores and injection wells as means of environmental control have become the spirit of place of the 3G Kampong. Signage and infographic which describes this water conservation movement have been placed in the main road area of the 3G Kampong These are expected to educate visitors while showing the importance of the existence of the bio pores and injection wells. As a tourist destination, the $3 \mathrm{G}$ Kampong has partnered up with several parties and produced public spaces that still carry the spirit of greening as environmental controllers. One of them is the Eco Edu Park Park which is a CSR program by BRI.
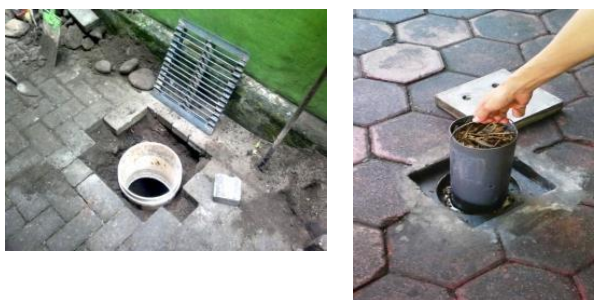

Figure.3. Biopores holes in every corner of the 3G Kampong.(researcher documentationn every corner of t, 2018)

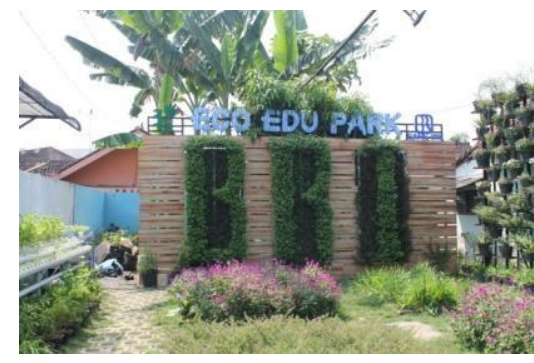

Figure.4. Eco Edu Park (researcher documentation, 2018)

Rows of plants display on the entrance area and the main road of the $3 \mathrm{G}$ Kampong work as a marker and controller of the surrounding environmental conditions. Beside that, these various plants are also arranged aesthetically in order to become an attractive public space for visitors. The increased awareness of the kampong community is supported by the right thematic village management in determining the steps of innovation and partnering has made the $3 \mathrm{G}$ Kampong as a thematic village that does not only sell visualization but also provide education. This is what distinguishes the $3 \mathrm{G}$ Kampong wih any other thematic villages, the $3 \mathrm{G}$ Kampong appears as an answer to existing environmental problems, aesthetic visualization of the kampong is an added value of the existence of the greening area. While other thematic villages offer more visual appeal, the village has implemented the Genius Loci concept by elevating greening and water conservation as the spirit of place and finding its main function in revitalizing its environment so that the $3 \mathrm{G}$ Kampong has a high sustainability value.

\section{Analysis and Evaluation of Fuctional Frame}

According to the functional frame, a good built environment must be able to accommodate activities carried out by humans refer simply to the reference number, as in [4]. The 3G Kampong can ecologically meet the needs of users for healthy, green and flood-free settlements. The spaces formed in this region are divided into several zones. The first zone is the main gate and road area. The main road has a high barrier wall and a 5 meters road width. On the right and left side of the building, there are various plants that are planted and arranged using urban farming techniques, including hydroponics, vertical garden, sky garden and polybags. Plants that are planted vary, such as medicinal plants, vegetable plants, fruit plants and flowers. This greening area besides carrying out the environmental control function as a provider of clean air, this area is also arranged aesthetically to fulfill the activity of visitors who want to take pictures

The next zone is the house of kampong chairperson. This house better known as "Rumah Prestasi". "Rumah Prestasi" is an information center for visitors who want to know about the $3 \mathrm{G}$ and water conservation movement. In addition to the green area on the right and left side of the main road and alley road, there is a third zone in form of open space, namely Eco Edu Park which also functions as a reforestation area, water conservation and education place. Eco Edu Park is the work or idea of local residents 
and has the full support of Bank Rakyat Indonesia. Eco Edu Park has infiltration ditches, infiltration wells, biopores, planting technology and also hydroponics with various types of plants. Supported by aesthetic garden arrangement, this area is also used as a photo spot to accommodate the activity of visitors who want to take pictures.

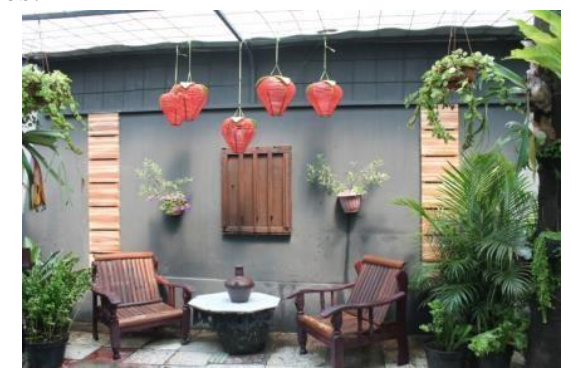

Figure.5. Photo spots in The 3G Kampong Reforestation Area (researcher documentation, 2018)

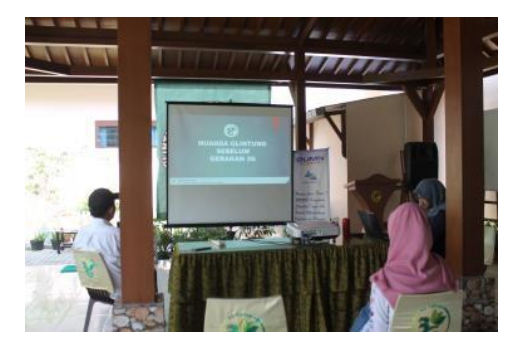

Figure.6. Pendopo as a public area , (researcher documentation, 2018)

The fourth zone is BSM (Malang Garbage Bank)

Dewandaru. It is a waste collection center in Glintung village where the wasted will be sold and the results will be shared with all residents. Empty land which is widely used by residents as a garbage collection center. The fifth zone is a pendapa with a joglo roof. This pendapa is a public area used by residents and visitors to hold discussions, workshops and seminars. Pendapa in the $3 \mathrm{G}$ Kampong is a large room without insulation. Like its function in Javanese culture, this space is often used as a meeting place for large events for its inhabitants, the kampong pendopo is also used to hold community meetings and places to receive visitors. Along the main road and alley there are various sizes of biopori holes and injection wells. The function of the biopore is to accelerate the absorption of rainwater so that it can prevent flooding and landslides and overcome organic wasted which causes an increase in water reserves and fertile soil. While injection wells can improve soil infiltration capabilities and help reduce the flow of surface runoff so as to prevent and reduce floods and puddles. Laying biopore holes and injection wells throughout the Kampong $3 \mathrm{G}$ areas to maximize revitalization of the village to avoid flooding.

From the analysis of ecological function aspects, The 3G Kampong has been able to meet the needs and activities of citizens. As a tourist destination, The $3 \mathrm{G}$ Kampong has accommodated visitors to take photos through the photo area. However, changes in private areas into public areas have not yet accommodated some visitor activities such as counters, parking areas, rest areas, guesthouses and shops that sell typical kampong merchandise.

\section{Analysis and Evaluation of Social Millieu}

Social millieu is a static expression, role, group, association, institution and group of buildings that can present a social system as a whole. In general, it can be said that the roles and rules in human relations are forming what so called part of the role of the building or built environment. The building and its environment provide and accommodate human life and the right environment for general or special activities. Those statements refer simply to the reference number, as in [4]

In the forming of the $3 \mathrm{G}$ Kampong environment, there are existing social system such as the relationship of the kampong chairperson, leader of the neighborhood and the community. However, in the creation and development of the $3 \mathrm{G}$ Kampong, the dominating social system is the relationship between the kampong chairperson and residents. In addition to these relationships, there are also social relations between citizens and the social relations of citizens with visitors.

The realization of this social relationship shows in the existence of several public spaces in this region. Before the village was built, many coordination activities were carried out at the Kampong Hall. However, after the 3G Kampong was built, there was an increase in the existing social relations, namely the relationship between residents and visitors, this encouraged residents to build a Pendopo in the middle of the $3 \mathrm{G}$ Kampong area which was used to conduct socialization, coordination and workshops. The Pendopo adjacent to the Dewandaru garbage bank and Eco Edu Park shows that this area is a center of social activity for residents with visitors. In addition to showing the social relations of citizens with visitors, several private spaces has turned into public spaces in the form of shops.

All activities in forming the 3G Kampong environment are based on mutual cooperation and it has produced "Dalu Tribe", namely the people doing mutual cooperation to improve the village at night. The social relations that exist between the residents and the Kampong Chairperson also give residents an economic boost through the Dewandaru Malang Waste Bank. The Dewandaru is a waste collection center in the $3 \mathrm{G}$ Kampong, then after being taken full by the central garbage bank for sale. The sales are distributed to residents each year ahead of Eid al-Fitr, the dominance of the social role of the kampong chairperson in forming the $3 \mathrm{G}$ Kampong is very large. Every citizen who wants to get a signature for whatever letter must plant crops in his house. Visually, this is evident in the term kampong chairperson housing on signage, where the house is named Rumah Prestasi. Every visitor who wants to learn about reforestation and water conservation of the settlement can go to Rumah Prestasi to find data.

From the explanation above, it can be observed that the social relations that occur in the region have been very well established. The kampong chairperson as the coordinator of the community has carried out its function, the social relations of the citizens embodied in mutual cooperation to form green open spaces into the spirit of place of Kampung 3G. Proactive citizens are one of the 
social milleu aspects that support the sustainability of a thematic village.

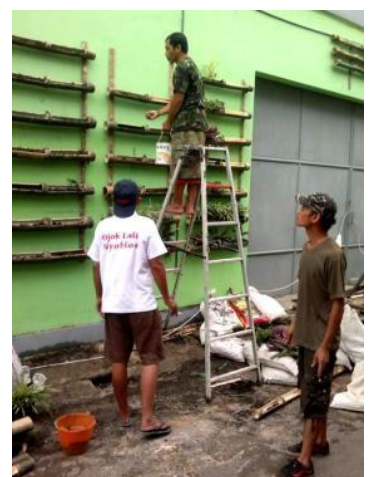

Figure.7. Mutual Cooperation Culture (researcher documentation, 2018)

\section{E. Analysis and Evaluation of Cultural Symbolization}

A built environment can become a symbol of a particular culture, it is closely related to the social milieu aspect, where social millieu influences the symbols that occur refer simply to the reference number, as in [3]. In the 3G Kampong environments, aspects of cultural symbolization appear in mutual cooperation in managing and revitalizing the environment. In addition, the dominance of the social role of the kampong chairperson in shaping public awareness of a healthy environment also accelerates the realization of a sustainable thematic 3G Kampong.

The aspect of spatial cultural symbolization can be felt when entering and walking on the main road of the 3G Kampong. Narrow land does not deter people's creativity, planting techniques on narrow land such as polybags, vertical gardens, hydroponics, and sky garden dominates the village environment. In addition, aiming to provide physical control of the environment, various plants in the $3 \mathrm{G}$ Kampong provide green dominance in the area. The green color brings a refreshing impression because it is associated with nature and plants. Green color provides a sense of security, as well as balance and harmony. This color is suitable for use in residential areas because it brings a feeling of peace and tranquility.

Some residents have made the $3 \mathrm{G}$ movements a part of their culture and identity of their village. This shows in the existence of plants in the house as private areas of the residents. The habit of making regular direct contact with plants and the natural environment can improve a person's physical health and mental well-being. This condition indirectly not only symbolizes the environment of the $3 \mathrm{G}$ Kampong which is environmentally friendly but also the health and mental well-being of the citizens that increases.

The aspect of cultural symbolization in the $3 \mathrm{G}$ Kampong is formed from areas of reforestation and water conservation that convey the message of mutual cooperation to the Indonesian people. Changing the role of the $3 \mathrm{G}$ Kampong into a new tourist destination that has photo spot facilities for visitors as part of a thematic village is a symbol of millennial culture

\section{CONCLUSION}

Genius loci or spirit of place in the $3 G$ Kampong is located in the green spaces formed by mutual cooperation culture and the high participation and awareness of citizens about the revitalization of their environment. The application of the physical control aspect in the form of creating green areas and conserving water is the most prominent aspect of the 3G Kampong. Physical Control aspects can be successful if supported by the social aspects of the citizens in the form of mutual cooperation and go green lifestyle. So that in the end the functional frame aspect of the environment is achieved and the green spaces become a symbol of the mutual cooperation between the villagers. The $3 \mathrm{G}$ Kampong has implemented the Genius Loci concept in its design and if the thematic kampong trend fades, this kampong can certainly have sustainability.

\section{ACKNOWLEDGMENT}

This research was supported by Brawijaya University. We also gratefully thank Ir. Bambang Irianto as chairman of The 3G Kampong for his contribution to provide our basic research data and the resident of $3 \mathrm{G}$ Kampong for welcoming us warmly.

\section{REFERENCES}

[1] Heryati, "Kampung Kota Sebagai Bagian Dari Permukiman Kota (Studi Kasus Tipologi Permukiman Rw 01 Rt 02 Kelurahan Limba B

Dan Rw 04 Rt 04 Kel. Biawu Kecamatan Kota Selatan Kota Gorontalo)" in Jurnal Inovasi, vol. 8 no. 3, Bandung: Ikatan Mahasiswa Pascasarjana dan Alumni Gorontalo, 2011, pp.102-117

[2] Tamara, Anindya Putri \& Rahdriawan, Mardwi. "Kajian Pelaksanaan Konsep Kampung Tematik di Kampung Hidroponik Kelurahan Tanjung Mas Kota Semarang," in Jurnal Wilayah dan Lingkungan, vol. 6 no.1, Semarang: Diponegoro University, 2018, pp. 40-57 [3] Kłoczko-Gajewska, A, "General characteristics of thematic villages in Poland", in Visegrad Journal on Bioeconomy and Sustainable Development, vol.2 no. 2, Nitra: Slovak University of Agriculture, 2013, pp. 60-63

[4] Norberg-Schulz, Christian. Genius Loci, Towards a Phenomenology of Architecture. Edinburgh: Edinburgh College of Art Library, 1980

[5] Elzeser, Sonja Stojmenska, Representation and Production of the Genius Loci in Literature. Skopje: Ss. Cyril and Methodius University, 2013 